\title{
Influence of Sulfide Compounds on the Metabolism of Methanobacterium Strain AZ
}

\author{
A. WELLINGER* and K. WUHRMANN
}

Swiss Federal Institute of Technology Zürich and Federal Institute for Water Resources and Water Pollution Control, Ueberlandstr. 133, CH-8600 Dübendorf, Switzerland

Abstract. Various organic sulfides and inorganic sulfide were studied in respect to their effect on growth and methane production of Methanobacterium strain AZ. In mineral, sulfide-free medium, cysteine regulated the specific rate of methane production (optimum concentration $\left.=5 \cdot 10^{-4} \mathrm{~mole} / 1\right)$. A supplement of sulfide $\left(10^{-4} \mathrm{~mole} / \mathrm{l}\right)$ caused an additional stimulation. Coenzyme $M^{* *}$ or glutathione could be substituted for cysteine when sulfide was present. Growth was stimulated by CoM and glutathione to the same extent as with cysteine in sulfide-containing media. The concentration of sulfide in cysteine-containing media affected the excretion of amino acids.

Key words: Methanobacterium strain $\mathrm{AZ}$ - Growth and methane formation - Role of cystine, sulfide, CoM and glutathione.

Barker (1940) observed that in the absence of $\mathrm{H}_{2} \mathrm{~S}$, growth of $M$. omelianskii was delayed or absent and that higher concentrations $(\leq 8 \mathrm{mg} / 100 \mathrm{ml})$ inhibited growth completely. Bryant et al. (1971) showed that in cultures of M. ruminantium strain PS (a strain from sewage sludge), sulfide acted as a sulfur source rather than as a reducing agent. In addition, they found that either sulfide or cysteine could serve as sulfur source for Methanobacterium strain M.O.H. A supply of cysteine to cultures growing on sulfide increased growth remarkably. Using titanium(III) citrate as a redox buffer, Zehnder and Wuhrmann (1977) demonstrated that cysteine is, independently of its potential activities as a reductant, an essential amino acid for growth of strain AZ. However, addition of sulfide caused a

* Present address: Department of Dairy Science, University of Illinois, Urbana, Ill. 61801, U.S.A.

Abbreviations. $\mathrm{CoM}=$ Coenzyme $\mathrm{M} ; \mathrm{HS}-\mathrm{CH}_{2}-\mathrm{CH}_{2}-\mathrm{SO}_{3}$ (Taylor and Wolfe, 1974) supplementary increase of methane production and growth. The optimum concentration found $\left(10^{-4}\right.$ mole/l) coincides with the sulfide concentration in the rumen (Hungate, 1966).

The present paper was initiated to investigate the role of sulfhydril compounds in Methanobacterium strain AZ. Various effects on growth and methane formation as well as on amino acid excretion were demonstrated.

\section{MATERIALS AND METHODS}

Growth Media. Stock solutions were prepared as described previously (Zehnder and Wuhrmann, 1977): $1 . \mathrm{KH}_{2} \mathrm{PO}_{4}, 27.2 \mathrm{~g}$ in $1000 \mathrm{ml}$ $\mathrm{H}_{2} \mathrm{O}$. 2. $\mathrm{Na}_{2} \mathrm{HPO}_{4}, 28.4 \mathrm{~g}$ in $1000 \mathrm{ml} \mathrm{H} \mathrm{H}_{2} \mathrm{O}$. 3. Mineral solution: $\mathrm{NH}_{4} \mathrm{Cl}, 6 \mathrm{~g} ; \mathrm{NaCl}, 6 \mathrm{~g} ; \mathrm{CaCl}_{2} \cdot 2 \mathrm{H}_{2} \mathrm{O}, 2.2 \mathrm{~g} ; \mathrm{MgCl}_{2} \cdot 6 \mathrm{H}_{2} \mathrm{O}, 2 \mathrm{~g}$ in $1000 \mathrm{ml} \mathrm{H}$ O. 4. $\mathrm{NaHCO}_{3}, 80 \mathrm{~g}$ in $1000 \mathrm{ml} \mathrm{H}_{2} \mathrm{O}$. 5. Trace metal solution: $\mathrm{H}_{3} \mathrm{BO}_{3}$ saturated solution, $1 \mathrm{ml} ; \mathrm{FeCl}_{2} \cdot 2 \mathrm{H}_{2} \mathrm{O}, 2 \mathrm{~g}$; $\mathrm{ZnCl}_{2}, 0.05 \mathrm{~g} ; \mathrm{MnCl}_{2} \cdot 4 \mathrm{H}_{2} \mathrm{O}, 0.5 \mathrm{~g} ; \mathrm{CuCl}_{2} \cdot 2 \mathrm{H}_{2} \mathrm{O}, 0.03 \mathrm{~g}$; $\left(\mathrm{NH}_{4}\right)_{6} \mathrm{Mo}_{7} \mathrm{O}_{24} \cdot 4 \mathrm{H}_{2} \mathrm{O}, 0.05 \mathrm{~g} ; \mathrm{AlCl}_{3}, 0.05 \mathrm{~g} ; \mathrm{CoCl}_{2} \cdot 6 \mathrm{H}_{2} \mathrm{O}, 2 \mathrm{~g}$; $\mathrm{HCl}$ conc. $1 \mathrm{ml}$ in $1000 \mathrm{ml} \mathrm{H}$ O. 6 . Vitamin solution: according to Wolin et al. (1963). 7. Titanium(III) solution $6 \cdot 10^{-2}$ molar (Zehnder and Wuhrmann, 1976). 8. Sulfide solution: $\mathrm{Na}_{2} \mathrm{~S} \cdot 9 \mathrm{H}_{2} \mathrm{O}$, $24.02 \mathrm{~g}$ in $100 \mathrm{ml} \mathrm{H}_{2} \mathrm{O}$.

The mineral medium was prepared as follows: $20 \mathrm{ml}$ of solution (1) and $47 \mathrm{ml}$ of solution (2) were made up with distilled water to $900 \mathrm{ml}$ and sterilized at $120^{\circ} \mathrm{C}$. One milliliter of trace metal solution (5) and $1 \mathrm{ml}$ of vitamin solution (6) in $50 \mathrm{ml}$ of mineral solution (3) were added aseptically to the autoclaved medium by filtering through a $0.2 \mu$ membrane filter (Sartorius). If not stated otherwise, $0.08 \mathrm{~g}$ of cysteine $\mathrm{HCl}$ in $50 \mathrm{ml}$ of solution (4) were supplemented in the same way. After gassing the medium with $20 \% \mathrm{CO}_{2}$ and $80 \% \mathrm{H}_{2}$ to remove all oxygen, $30 \mathrm{ml}$ of titanium(III) solution were introduced and the sulfide solution (8) added according to experimental requirements.

The complex medium is identical to the mineral medium with the exception that $2.5 \mathrm{~g}$ of yeast extract were dissolved in the mixture of solutions (1) and (2) before autoclaving.

Culture Technique. The Hungate technique $(1950,1969)$ modified by Bryant and Robinson (1961) was adapted for the cultivation of $100 \mathrm{ml}$ cultures in 11 serum bottles with serum caps (diameter $35 \mathrm{~mm}$ ). The media were prepared and sterilized in these bottles as described above. Temperature was $33^{\circ} \mathrm{C}, \mathrm{pH}$ was set to 7.2 $\left(\mathrm{PO}_{4}\right.$ buffer solution no. 1 and 2$)$. 
Table 1. Methane formation as a function of sulfide concentration. Mineral medium, cysteine concentration: $10^{-3} \mathrm{~mole} / 1$, gas phase $\mathrm{H}_{2}: \mathrm{CO}_{2}=80: 20$, biomass $10 \mathrm{mg}$ dry weight in $100 \mathrm{ml}$ of medium, temperature: $33^{\circ} \mathrm{C}, \mathrm{pH} 7.2$

\begin{tabular}{|c|c|c|c|c|c|}
\hline \multirow{2}{*}{$\begin{array}{l}\text { Time } \\
\text { (min) }\end{array}$} & \multicolumn{4}{|c|}{ Sulfide (mole/1) } & \multirow[b]{2}{*}{$10^{-6}$} \\
\hline & 0 & $10^{-3}$ & $10^{-4}$ & $10^{-5}$ & \\
\hline & \multicolumn{5}{|c|}{ Cumulative $\mathrm{CH}_{4}$ formation, $\mu$ moles $\cdot \mathrm{mg}$ dry weight ${ }^{-1}$} \\
\hline 100 & 12.05 & 21.88 & 22.32 & 20.09 & 13.84 \\
\hline 200 & 24.11 & 39.29 & 41.07 & 34.38 & 29.02 \\
\hline 290 & 36.16 & 56.25 & 61.16 & 58.48 & 43.30 \\
\hline \multirow[t]{3}{*}{380} & 49.55 & 70.09 & 79.46 & 70.09 & 56.25 \\
\hline & \multicolumn{5}{|c|}{ Rate of $\mathrm{CH}_{4}$ formation, $\mu$ moles $\cdot \mathrm{g}$ dry weight ${ }^{-1} \cdot \mathrm{min}^{-1}$} \\
\hline & 125 & 192 & 210 & 196 & 147 \\
\hline
\end{tabular}

Bacterial Growth. The optical density was measured in $1 \mathrm{~cm}$ cuvettes at $578 \mathrm{~nm}$ using an Eppendorf photometer. Dry weights were determined on Sartorius membrane filters no. 11306 with $0.45 \mu \mathrm{m}$ pore size.

Harvesting of Cells. The cultures were transferred anaerobically into small serum bottles $(120 \mathrm{ml})$ previously flushed with a mixture of $80 \% \mathrm{H}_{2}$ and $20 \% \mathrm{CO}_{2}$. The cells were centrifuged under slight overpressure for $20 \mathrm{~min}$ at $1500 \mathrm{~g}$, and the supernatant blown out by the gas mixture.

Amino Acid Analysis. $5 \mathrm{ml}$ samples were taken from culture vessels with sterile disposable syringes. After acidification to $\mathrm{pH} 2$ with $\mathrm{HCl}$ conc., they were centrifuged $(10 \mathrm{~min}, 30000 \mathrm{~g})$. Neutral and acid amino acids in the supernatant were determined by column chromatography on a Biocal Instrument AA analyzer.

Gas Measurements. Methane was detected with a Gow Mac gaschromatograph equipped with a porapak Q (80/100 mesh) column and a molecular sieve ( $80 / 100$ mesh) column connected to a thermal conductivity detector. Samples were taken with a sterile gas-tight syringe. Absolute gas content was calculated on the basis of manometric pressure measurements.

Coenzyme $M$. Generously supplied by Prof. R. S. Wolfe.

All chemicals were obtained from commercial sources.

\section{RESULTS}

\section{Effect of Sulfide on Methane Formation}

Addition of various amounts of sulfide to cultures in mineral medium containing cysteine as sole sulfur source caused significant differences in the rate of methanogenesis within about 100 min (Table 1). This is a very fast response when compared with the generation time of approx. $58 \mathrm{~h}$ for strain $\mathrm{AZ}$ in this medium. The optimum concentration of inorganic sulfide for this stimulation was $10^{-4}$ mole/l which confirms the previous findings of Zehnder and Wuhrmann (1976).

\section{Effect of Cysteine on Methane Formation}

Cells from cultures grown in mineral medium were harvested anaerobically, washed twice with oxygen- free phosphate buffer ( $\mathrm{pH} 7.2,1 / 75$ mole/l) and incubated in mineral medium devoid of sulfide and cysteine. For about two generation times, the growth rate remained unchanged, i.e. corresponded to cultures in cysteine-containing media which indicates the presence of a certain cysteine pool in the organisms. Once this reserve was exhausted, growth stopped. At this stage, the cells were harvested and transferred to another sulfur-free medium. Addition of cysteine to such sulfur-impoverished cultures revealed a clear dependence of the specific methane production on cysteine concentration (optimum at $5 \cdot 10^{-4} \mathrm{~mole} / \mathrm{l}$, Fig.1). A supply of sulfide $\left(10^{-4}\right.$ mole/l) in addition to cysteine increased methane formation significantly. Without cysteine, i.e. in the absence of growth, the remaining methanogenesis (which can be considered as endogenous methane formation) is independent of the presence of sulfide in the medium.

\section{Effect of Methane Formation of Compounds Chemically Related to Cysteine}

Five sulfide-containing organic compounds (in parenthesis the final concentrations): homocysteine $\left(10^{-4} \mathrm{~mole} / \mathrm{l}\right)$, S-methylcysteine $\left(10^{-4} \mathrm{~mole} / \mathrm{l}\right)$, glutathione $\left(10^{-4} \mathrm{~mole} / \mathrm{l}\right)$, dimethyldisulfide $\left(10^{-4} \mathrm{~mole} / \mathrm{l}\right)$ and coenzyme $\mathrm{M}$ (HS-CoM, $15 \mathrm{ng}$ per ml medium) were tested for their ability to enhance methane production by sulfur-depleted cells. The effects were compared with cultures in cysteine-containing media $\left(5 \cdot 10^{-4} \mathrm{~mole} / \mathrm{l}\right)$ and control cultures without any sulfur addition. In the absence of sulfide, cysteine was the only compound to stimulate methanogenesis. In the presence of sulfide $\left(10^{-4} \mathrm{~mole} / 1\right), \mathrm{CoM}$ and glutathione accelerated methane formation (Fig. 2) although to a lesser extent than cysteine. The other compounds had no effect. Whether this might have been due to lack of uptake by cells was not examined. 

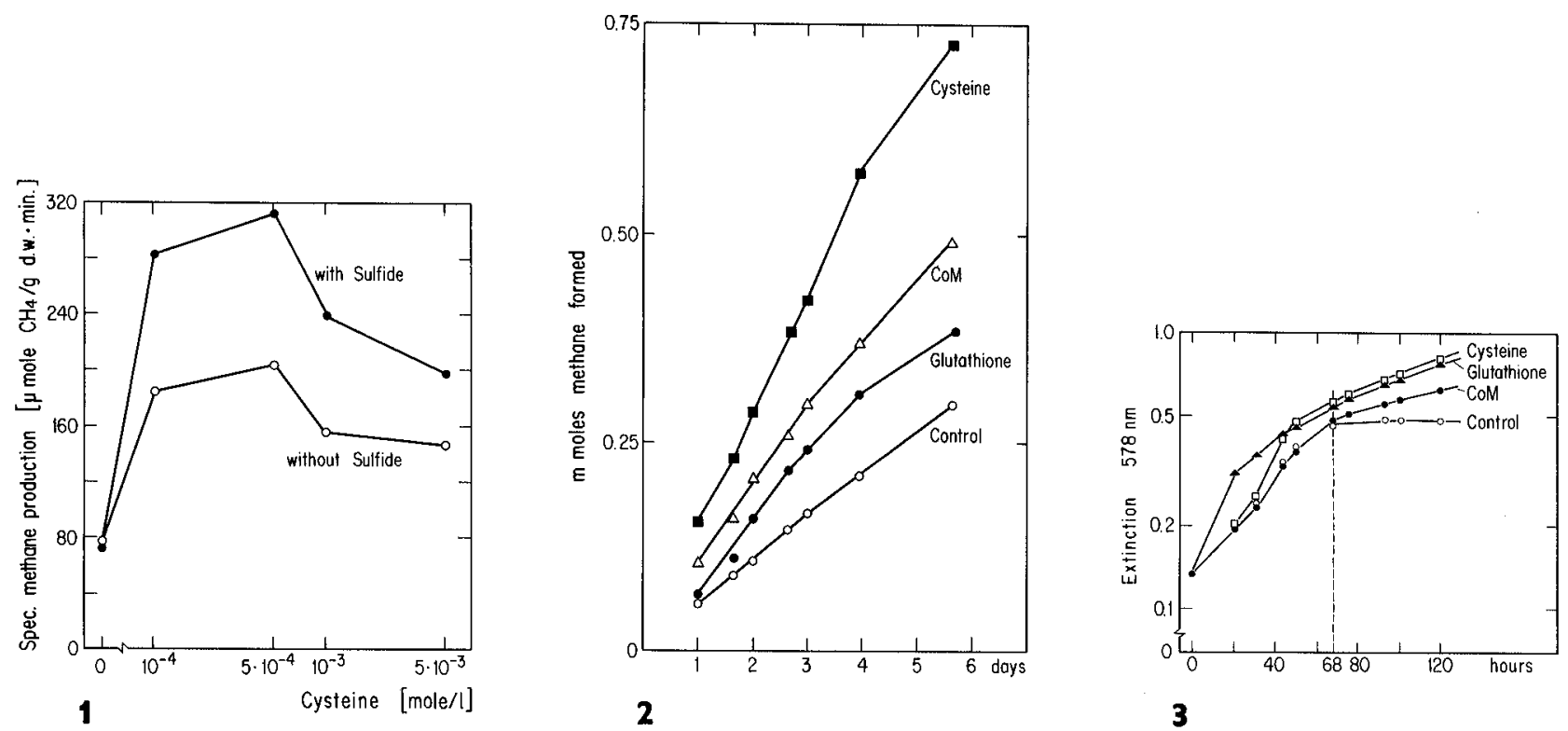

Fig. 1. Effect of cysteine on the specific methane production of strain AZ. Inoculum: sulfur impoverished culture. Medium: mineral medium with cysteine concentrations as indicated. Open circles: without sulfide; closed circles: with sulfide $10^{-4}$ mole/1. Volume of the culture medium: $100 \mathrm{ml}$; $\mathrm{pH} 7.2$; temperature $33^{\circ} \mathrm{C}$; gas phase $\mathrm{H}_{2}$ and $\mathrm{CO}_{2}(80: 20)$

Fig. 2. Effect on methane formation of compounds chemically related to cysteine. Inoculum: sulfur impoverished culture. Dry weight $1 \mathrm{mg}$. Medium: mineral medium without cysteine; volume: $25 \mathrm{ml}$; sulfide concentration: $10^{-4}$ mole 11 ; pH $7.2 ;$ temperature: $33^{\circ} \mathrm{C}$; gas phase: $\mathrm{H}_{2}$ and $\mathrm{CO}_{2}(80: 20)$. The following sulfur compounds had been added prior to inoculation: $\mathrm{O}$ none; glutathione $\left(10^{-4}\right.$ mole $\left./ 1\right)$; $\Delta \mathrm{CoM}\left(15 \mathrm{ng}\right.$ per $\mathrm{ml}$ medium); $\mathbf{a}$ cysteine $\left(5 \cdot 10^{-4}\right.$ mole $\left./\right)$

Fig. 3. Influence of CoM and glutathione on growth of strain AZ. Inoculum: precultured on complex medium. Medium: mineral medium without cysteine; volume: $100 \mathrm{ml}$; $\mathrm{pH} 7.2$; temperature: $33^{\circ} \mathrm{C}$; gas phase: $\mathrm{H}_{2}$ and $\mathrm{CO}_{2}(80: 20)$. The following substances had been added prior to inoculation: O none; $\operatorname{CoM}\left(30 \mathrm{ng}\right.$ per $\mathrm{ml}$ medium); $\Delta$ glutathione $\left(2 \cdot 10^{-4}\right.$ mole $\left./ 1\right)$ or glutathione $\left(2 \cdot 10^{-4}\right.$ mole/l) plus cysteine $\left(5 \cdot 10^{-4} \mathrm{~mole} / \mathrm{l}\right) ; \mathbf{D}$ cysteine $\left(5 \cdot 10^{-4} \mathrm{~mole} / \mathrm{l}\right)$

\section{Influence of CoM and Glutathione on Growth of Strain AZ}

Strain AZ shows best growth in a medium containing yeast extract (Zehnder, 1976). The author found that the "stimulating factor" in yeast extract is stored by the bacteria and may provide for normal growth in mineral medium for approximately $2^{1 / 2}$ generations. For further elucidation of this effect, the following experiment was started:

Cysteine-free mineral media (containing $10^{-4}$ mole $\left.\mathrm{S}^{2-} / 1\right)$ to which were added either CoM $(30 \mathrm{ng} / \mathrm{ml}$ medium) or glutathione $\left(2 \cdot 10^{-4} \mathrm{~mole} / 1\right)$ or cysteine $\left(5 \cdot 10^{-4}\right.$ mole/l) or cysteine $\left(5 \cdot 10^{-4}\right.$ mole/l) plus glutathione $\left(2 \cdot 10^{-4} \mathrm{~mole} / 1\right)$, and a control without additions were inoculated with washed cells precultured in complex medium and incubated as usual. The results (Fig. 3) indicate that growth of the control and of the cultures with cysteine and CoM started at identical rates. Glutathione-containing cultures grew somewhat faster. After about 2 generations, the control culture ceased growing whereas in the other cultures the biomass increase continued, although at a slightly decelerated rate.
The conclusion is that none of the additions could fully replace the essential growth factor(s) in yeast extract. As with methane formation, it is again evident, however, that CoM in the presence of sulfide may take over the role of cysteine in cell growth as well.

\section{Effect of Sulfide and Cysteine on the Excretion of Amino Acids}

Various amino acids accumulated in the medium during growth of strain AZ. Table 2 summarizes the analytical results from two parallel cultures in mineral medium containing $5 \cdot 10^{-4}$ mole $/ 1$ cysteine; one of them was supplied with $10^{-4} \mathrm{~mole} / \mathrm{l}$ sulfide. The amino acids accumulating in the culture solution after a lag period of about one day can be grouped as follows:

1. No notable excretion: methionine and proline.

2. Excretion clearly enhanced by sulfide in the external medium: glutamic acid, threonine and (to a lesser extent) aspartic acid; serine.

3. Excretion decreased by the presence of sulfide: valine, isoleucine, leucine. 
Table 2. Influence of inorganic sulfide $\left(10^{-4}\right.$ mole/l) on the amino acid excretion by growing cells of Methanobacterium strain AZ in cysteine-containing $\left(5 \cdot 10^{-4}\right.$ mole/1) mineral medium. Temperature: $33^{\circ} \mathrm{C}, \mathrm{pH} 7.2$, volume of culture medium: $100 \mathrm{ml}$

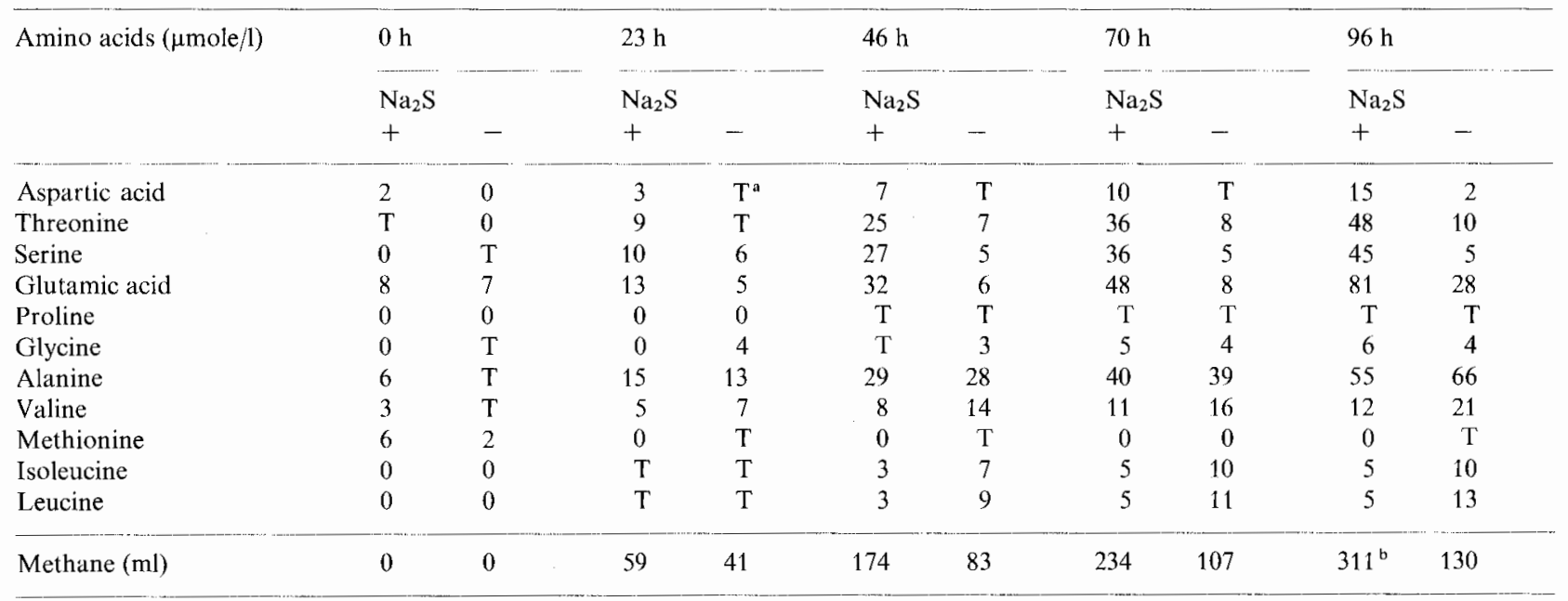

a T stands for "traces" and refers to amino acid concentrations $<2 \mu$ mole $/ 1$

b Final dry weight of cells $=16 \mathrm{mg}$

4. No or very slight effect of sulfide: alanine (strongly excreated), glycine (very slight excretion).

With the exception of serine, group 2 amino acids are synthesized from precursors formed in the tricarboxylic acid cycle. Group 3 and 4 acids are initially derived from pyruvate. This is also possible for serine, its alternative synthesis from $3 \mathrm{P}$-glycerate, however, has to be taken into consideration.

\section{DISCUSSION}

The interpretation of the experimental findings on the effect of inorganic or organic sulfides on growth, methane and amino acid production may be based on two points of view: 1) the need of strain $\mathrm{AZ}$ for inorganic sulfide and 2) the previous finding of Zehnder and Wuhrmann (1977) according to which cysteine is an essential amino acid. The pertinent observations concerning organic sulfides suggest the following conclusions: It is confirmed that cysteine must be considered as an essential amino acid when strain $A Z$ is grown in mineral medium. However, when CoM and sulfide are supplied, the need for cysteine can be covered, i.e. the external supply of CoM enables the formation of cysteine. The fact that catalytical amounts (approx. $5 \cdot 10^{-7}$ mole/l) of HS-CoM are sufficient to maintain methane production and growth in the presence of sulfide strongly indicates that CoM is a key coenzyme for strain $\mathrm{AZ}$ rather than an additional sulfur source. Therefore, the main sulfur source for strain AZ is sulfide. In a natural anaerobic environment, this need for sulfide for growth of strain $A Z$ may completely or partially be satisfied by cysteine.
The kinetic equilibrium between the rates of uptake of cysteine, cysteine incorporation, rate of internal sulfide liberation by desulfurication of cysteine on the one hand and the rate of synthesis of essential sulfur compounds on the other hand will then determine the need for additional inorganic sulfide.

We think that the effect of glutathione has to be interpreted on the same grounds: its resorption rate might be sufficient to cover the requirement for cysteine but not for an additional internal sulfur supply for synthesis of other essential sulfur compounds. Hence, its rate of uptake must be much lower than that of cysteine. Independent of the cysteine-CoM interrelationship, a second conclusion is suggested by the influence of sulfide on numerous anabolic processes by the accumulation of amino acids in the culture medium. On the premise that the excretion of amino acids indicates an excess of rate of synthesis in relation to incorporation rate into proteins, Table 2 shows clearly that

1. the appearance of amino acids in the medium derived from pyruvate is independent of the presence of additional sulfide (alanine, glycine) or is even increased in the absence of inorganic sulfide (valine, leucine, isoleucine). A simple explanation is that the formation of these amino acids at experimental conditions does not directly depend on sulfide supply. Their further utilization in protein synthesis, however, is sulfide-limited (except for alanine and glycine);

2. the excretion of amino acids, the precursors of which may be formed in the tricarboxylic acid cycle, is remarkably increased by the external sulfide supply (notably glutamic acid and threonine). This indicates 
a sulfur limitation of their synthesis when cysteine is the sole sulfur source.

It is not evident where sulfur might limit reactions within the tricarboxylic acid cycle, and its existence in methane bacteria has as yet not been demonstrated. The system of various sulfur-containing enzymes involved in the dehydrogenation of pyruvate to acetyl coenzyme A might, however, include reactions which are activated by high sulfide supplies to the cells. The presently available experimental evidence is insufficient for more detailed interpretations in this respect.

Acknowledgements. We are indebted to Prof. Marvin P. Bryant, Urbana (Il1.), for the critical review of this paper.

\section{REFERENCES}

Barker, H. A.: Studies upon the methane fermentation. IV. The isolation and culture of Methanobacterium omelianskii. Antonie van Leeuwenhoek 6, 201-220 (1940)

Bryant, M. P., Robinson, I. M.: An improved nonselective culture medium for ruminal bacteria and its use in determining diurnal variation in numbers of bacteria in the rumen. J. Dairy Sci. 44, 1446-1456 (1961)
Bryant, M. P., Tzeng, S. F., Robinson, I. M., Joyner, A. E.., Jr. Nutrient requirements of methanogenic bacteria. In: Anacrobic biological treatment processes. Advances in Chemistry Series 105 (F. G. Pohland, ed.), pp. 23-40. Washington, D.C. : Am. Chem. Soc. 1971

Hungate, R. E.: The anaerobic mesophilic celluloiytic bacteria. Bact. Rev. 14, 1-49 (1950)

Hungate, R. E.: The rumen and its microbes, p. 348. New YorkLondon: Academic Press 1966

Hungate, R. E.: A roll tube method for cultivation of strict anaerobes. In: Methods in microbiology, Vol. 3 B (J. R. Norris, D. W. Ribbons, eds.), pp. 117-132. New York-London: Academic Press 1969

Taylor, C. D., Wolfe, R. S.: Structure and methylation of Coenzyme $\mathrm{M}\left(\mathrm{HSCH}_{2} \mathrm{CH}_{2} \mathrm{SO}_{3}\right)$. J. Biol. Chem. 249, 4879-4885 (1974)

Wolin, E. A., Wolin, M. J., Wolfe, R. S.: Formation of methane by bacterial extracts. J. Biol. Chem. 238, 2882-2886 (1963)

Zehnder, A. J. B.: Oekologie der Methanbakterien. Dissertation, ETHZ, Nr. 5716. Zürich: Juris 1976

Zehnder, A. J. B., Wurhmann, K.: Titanium(III) citrate as a nontoxic oxidation-reduction buffering system for the culture of obligate anaerobes. Science 194, 1165-1166 (1976)

Zehnder, A. J. B., Wuhrmann, K.: Physiology of Methanobacterium strain AZ. Arch. Microbiol. 111, 199-205 (1977)

Received May 16, 1977 